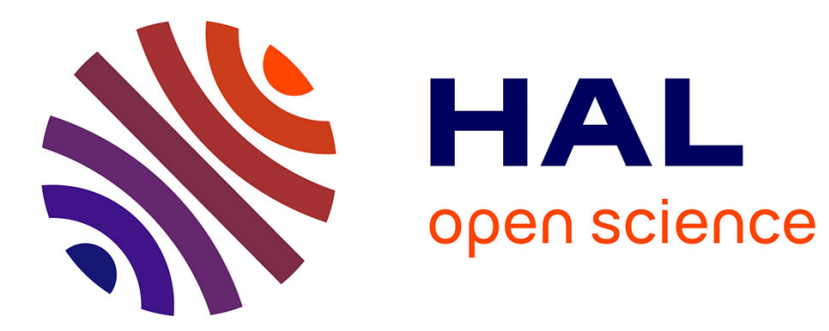

\title{
Elevated temperature plasma nitriding and effects on electrochemical properties of steel
}

K. Ram Mohan Rao, Kalimi Trinadh, Corinne Nouveau

\section{To cite this version:}

K. Ram Mohan Rao, Kalimi Trinadh, Corinne Nouveau. Elevated temperature plasma nitriding and effects on electrochemical properties of steel. Materials Today: Proceedings, 2019, 19, Part 2, pp.867-869. 10.1016/j.matpr.2019.08.227 . hal-03125676

\section{HAL Id: hal-03125676 \\ https://hal.science/hal-03125676}

Submitted on 29 Jan 2021

HAL is a multi-disciplinary open access archive for the deposit and dissemination of scientific research documents, whether they are published or not. The documents may come from teaching and research institutions in France or abroad, or from public or private research centers.
L'archive ouverte pluridisciplinaire HAL, est destinée au dépôt et à la diffusion de documents scientifiques de niveau recherche, publiés ou non, émanant des établissements d'enseignement et de recherche français ou étrangers, des laboratoires publics ou privés. 


\title{
Elevated temperature plasma nitriding and effects on electrochemical properties of steel
}

\author{
K. Ram Mohan Rao ${ }^{\mathrm{a}, *}$, Kalimi Trinadh ${ }^{\mathrm{a}}$, Corinne Nouveau ${ }^{\mathrm{b}}$ \\ a Department of Chemistry, GIS, GITAM-Deemed to be University, Visakhapatnam 530045, Andhra Pradesh, India \\ ${ }^{\mathrm{b}}$ Laboratoire Bourguignon des Matériaux et Procédés (LaboMaP), Arts et Métiers Paris Tech de Cluny, Rue Porte de Paris, F-71250 Cluny, France
}

A R T I C L E I N F O

Article history:

Received 31 July 2019

Accepted 13 August 2019

Available online 18 September 2019

\section{Keywords:}

Corrosion

Impedance

Polarization

Plasma

Steel

\begin{abstract}
A B S T R A C T
Surface modification of tool steel had been performed by utilizing plasma nitriding at elevated temperature by varying the exposure time. The nitrided steel had shown significantly enhanced corrosion resistance properties.

$\mathrm{X}$-ray diffraction (XRD) had revealed the presence of $\mathrm{Fe}_{\mathrm{x}} \mathrm{N}(\mathrm{x}=2-3,4)$ in the surface modified microstructure after nitriding. In an environment of $\mathrm{NaCl}$ potentiodynamic polarization and impedance (EIS) tests of steel with and without nitriding had been performed. Both these tests had shown the improved resistance to corrosion of the steel after nitriding.

(c) 2019 Elsevier Ltd. All rights reserved.

Selection and peer-review under responsibility of the scientific committee of the 1st International Conference on Manufacturing, Material Science and Engineering.
\end{abstract}

\section{Introduction}

Surface microstructural and the crystal lattice modifications had been proved to be the main reasons for the improvement of surface hardness, resistance to fatigue, wear and corrosion. The improvement of these properties has recently been realized in tool industries where the premature failure caused by the wear and corrosion in the service conditions demands the early replacement of the tools. Though the other processes like physical/chemical vapour deposition has been practiced to overcome these for a long time but the poor adhesion and delamination of the deposited layer had been the subject of concern [1-4]. Among the various surface modification methods plasma mediated nitriding has already been recognized as an environmental friendly and efficient process which has circumvented these limitations.

Formation of desirable nitride phases and the modification of surface microstructure, generation of stresses in the crystal lattice are well controlled and hence the process is successful and widely accepted for mechanical properties, corrosion and biocompatibility [5-15]. In the plasma nitriding process, the samples to be nitrided are polished to mirror finish and cleaned ultrasonically to remove the dirt on the surface. Samples are placed on the sample holder inside the nitriding chamber then evacuated to around $10^{-6}$ mbar. A mixture of nitrogen and hydrogen at certain ratio is then fed into

\footnotetext{
* Corresponding author.

E-mail address: rammohanrao.k@gmail.com (K. Ram Mohan Rao).
}

the chamber then triggered the plasma. Samples are biased negatively to attract the positively charged ions from the plasma towards itself. Sample temperature is raised to the desired level by auxiliary heater.

Nitrogen and hydrogen ions accelerate towards the surface, adsorb on the surface, diffuse towards the bulk of the sample and form the nitrides.

Though several works have been reported so far in the literature on nitriding of steel, however very less is known about the nitriding and corrosion of wood machining $\mathrm{CrMoV}$ martensitic steel. Previously, Corinne et al. shown an improvement of hardness similar steel and shown a significantly higher hardness of around $1150 \mathrm{H}_{v}$ than steel without nitriding which had $\sim 655 \mathrm{H}_{v}$ [9]. So far there is no sufficient literature on the electrochemical characterization of this steel after nitriding. Hence, an attempt has been made in the present work to understand the electrochemical corrosion this steel after nitriding in an environment of $3.5 \% \mathrm{NaCl}$. From the previous studies [9] it is understood that the hardness improvement is significant after nitriding at $500{ }^{\circ} \mathrm{C}$ but reduced when nitrided at $520^{\circ} \mathrm{C}$. Hence in the present studies the nitriding temperature was kept at $500^{\circ} \mathrm{C}$.

\section{Experimental details}

Austenitized steel was quenched in a bath of oil followed by tempering. Samples of dimension of $8 \times 8 \times 4 \mathrm{~mm}^{3}$ were cut from this steel then polished to mirror finish and cleaned with ultrasonic 
bath. The composition of the steel is given as: Carbon (0.5\%), Silicon (1\%), Manganese (0.5\%), Chromium (8.0\%), Molybdenum (1.5\%), Vanadium (0.5\%) and balance iron.

\subsection{Method}

Then samples was kept on the sample holder inside the nitriding chamber. By using rotary and diffusion pump vacuum to a pressure of $0.05 \mathrm{~Pa}$ was created in the chamber. Sample was negatively biased and with $\mathrm{Ar}+$ sputtering nitriding cycle initiated. Nitrogen and hydrogen at a ratio of 80:20 fed into the chamber. Nitriding was followed at $500 \mathrm{~Pa}$ when the temperature reached to $500^{\circ} \mathrm{C}$. After nitriding the samples with bare sample were exposed to detailed X-ray diffraction studies.

Bare and nitrided steel samples then subjected to corrosion tests by following potentiodynamic polarization and subsequently impedance spectroscopic tests (EIS) in an environment of 3.5\% $\mathrm{NaCl}$. The electrochemical testing was followed by using the system Model SI 1287-Solatron Analytical, U.K. The cell was consisting of nitrided sample, a saturated calomel (SCE) and Pt electrodes in $3.5 \% \mathrm{NaCl}$ already purged with nitrogen. The tests were conducted when once the equilibrium attained. The sample was scanned through $\pm 1 \mathrm{~V}$ at free atmosphere at the rate $1 \mathrm{mV} / \mathrm{s}$.

To further understand the corrosion behaviour of the nitrided and bare steel, electrochemical impedance spectroscopic analyses in $3.5 \% \mathrm{NaCl}$ was followed by using A.C. signals.

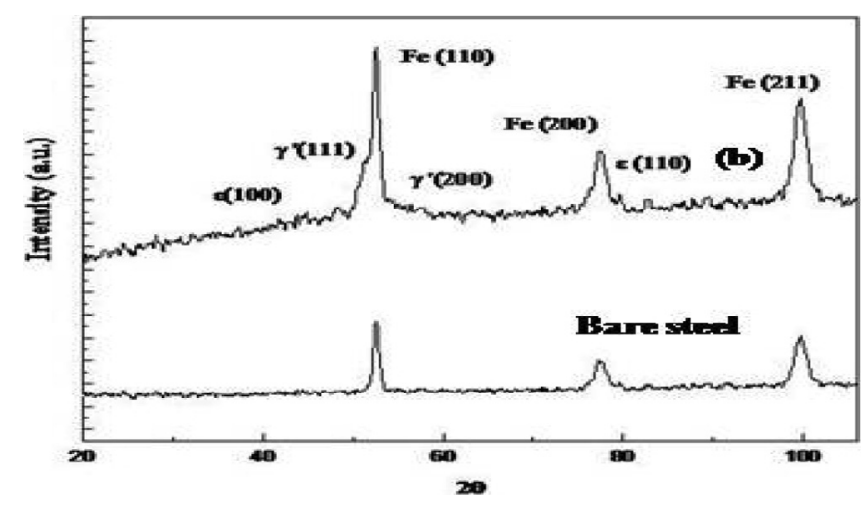

Fig. 1. X-ray diffractograms of (a) bare steel (S0) and nitrided samples at $500{ }^{\circ} \mathrm{C}$ for $8 \mathrm{~h}$ (b).

\section{Results}

\subsection{Phase evolution}

The nitrided and bare samples were exposed to detailed XRD analyses. Fig. 1 reveals the phases of bare and nitrided steel samples. From these XRD patterns it is found that the bare sample has only the Fe (1 10$)$, Fe (2 00$)$ and Fe (2 1 1 $)$ phase (Fig. 1a). The samples nitrided at $500{ }^{\circ} \mathrm{C}$ for $8 \mathrm{~h}$ (b) modified to the surface containing Fe-nitrides $\mathrm{Fe}_{\mathrm{x}} \mathrm{N}(\mathrm{x}=2-3,4)$. These peaks are $\gamma^{\prime}\left(\mathrm{Fe}_{4} \mathrm{~N}\right)$ along with $\varepsilon \mathrm{N}$.

$\varepsilon \mathrm{N}$ shows a good corrosion resistance. $\gamma^{\prime}\left(\mathrm{Fe}_{4} \mathrm{~N}\right)$ contributes to the hardness of the surface but the not so beneficial to corrosion resistances. Similarly, sample nitrided for $10 \mathrm{~h}$ shows both these nitrides.

\subsection{Electrochemical characterization}

For the samples before and after plasma nitriding corrosion tests were conducted in an electrolyte $\mathrm{NaCl}$ at room temperature. The electrochemical system Model SI 1287 ELECTROCHEMICAL INTERFACE-Solatron Analytical, U.K. was used for the tests.

\subsection{Stability of potential (O.C,P.)}

The bare and the nitrided steel samples were exposed to the electrolyte $3.5 \% \mathrm{NaCl}$ for a duration until a stable equilibrium state was attained. The steel nitrided at $500{ }^{\circ} \mathrm{C}$ had shown the decreased susceptibility towards corrosion. Initially a variation in corrosion potential was noted which ultimately reached to a stable state.

\subsubsection{Potentiodynamic polarization}

Potentiodynamic polarization tests were performed after equilibrium attained in $3.5 \% \mathrm{NaCl}$ electrolyte (Fig. 2).

From the polarization diagrams as shown in Fig. 3 the asreceived sample (a) has faster dissolution kinetics as compared to the nitrided steel (b). It has also been found that the other steel nitrided for longer time $10 \mathrm{~h}$ at the same temperature has similar dissolution kinetics. The rate of corrosion of as-received sample was found to be 3.6597 MPY much higher than the nitrided steel 1.8071 MPY.
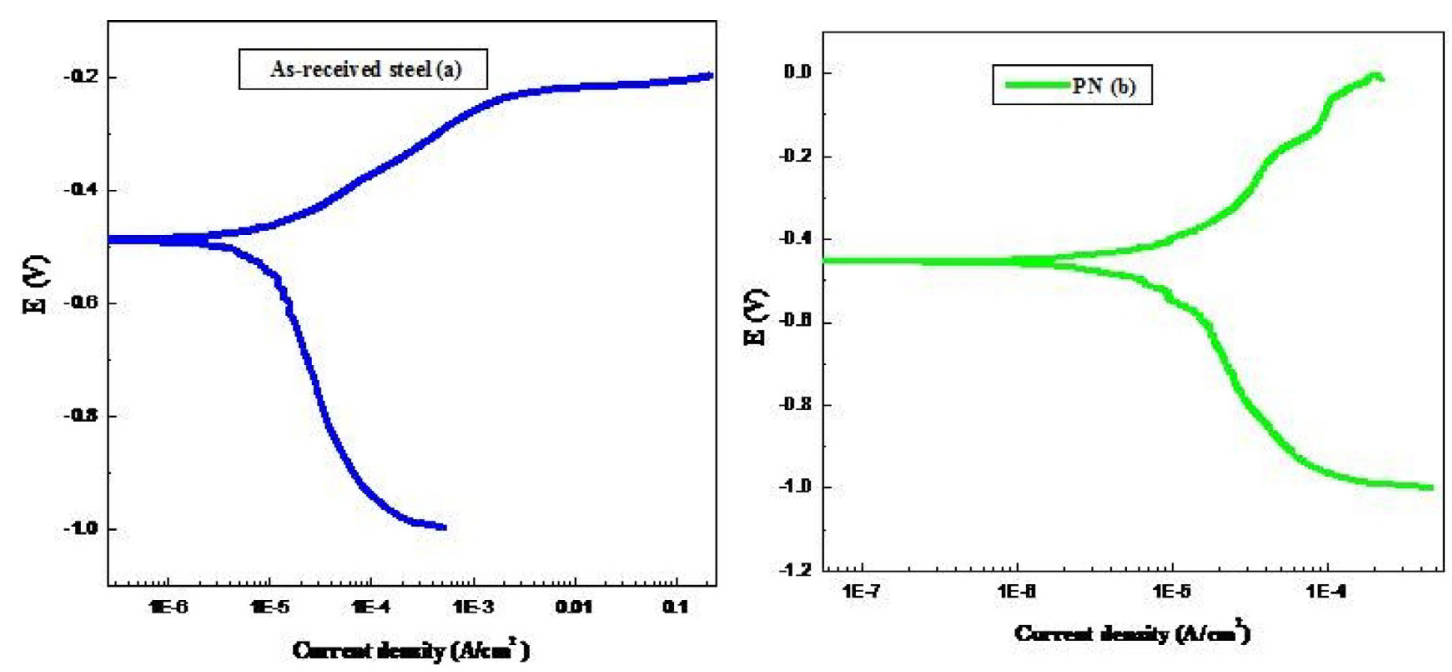

Fig. 2. Potentiodynamic polarization curves of (a) bare steel and (b) the nitrided steel at $500{ }^{\circ} \mathrm{C}$ for $8 \mathrm{~h}$. 

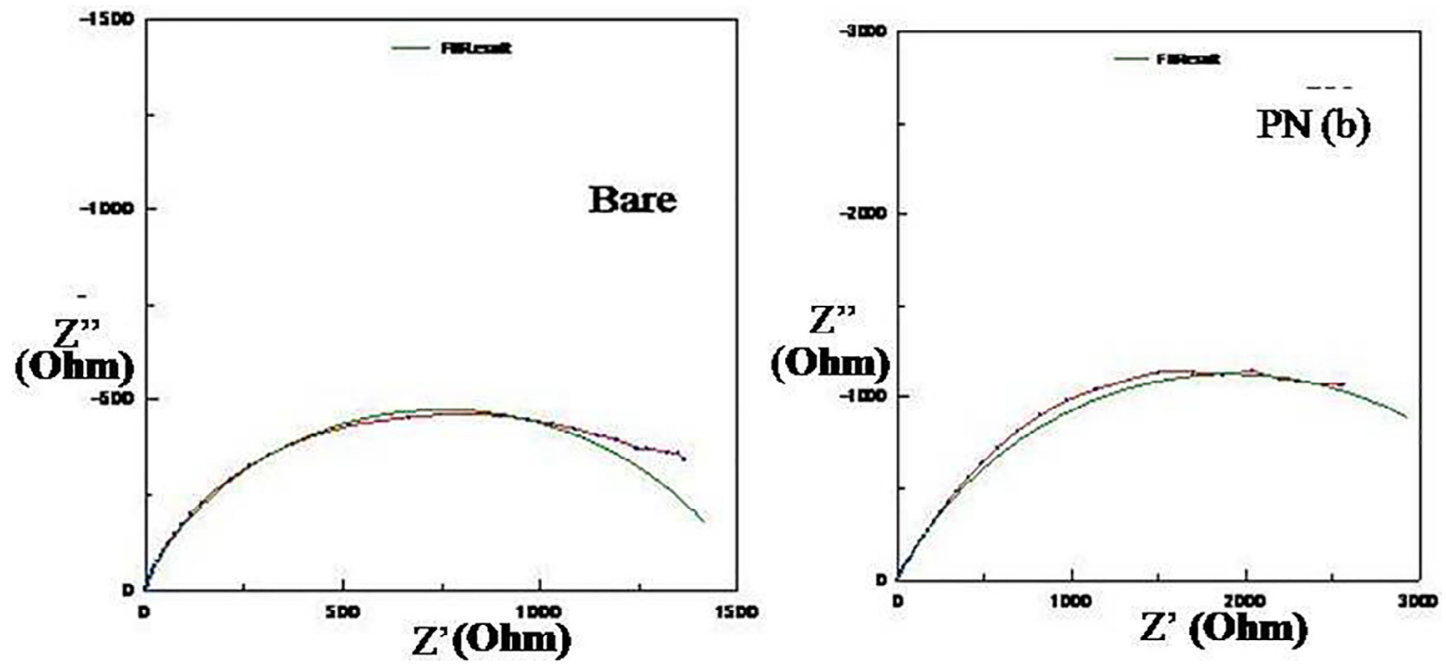

Fig. 3. Nyquist diagram of steel before and after $8 \mathrm{~h}$ nitriding $500{ }^{\circ} \mathrm{C}$.

\subsubsection{Corrosion tests by electrochemical impedance spectroscopy (EIS)}

Bare and nitrided samples were exposed to further tests by electrochemical impedance spectroscopic method in the electrolyte 3.5\% $\mathrm{NaCl}$.by using the system Model SI 1287 ELECTROCHEMICAL INTERFACE-Solatron Analytical, U.K.

In the above Nyquist plots the $Z^{\prime}$ represents impdance real and $Z^{\prime \prime}$ represents imaginary values. The $Z_{\text {real }}$ represents the resistance to corrosion. Higher the $Z_{\text {real }}$ value more will be the corrosion resistance i.e., the larger the diameter of the semicircle the greater will be the corrosion resistance. From the above Fig. 3 the plasma nitrided steel shows corrosion resistance more than the bare steel. From the XRD studies it is understood that after plasma nitriding the microstructure contains $\mathrm{Fe}_{\mathrm{x}} \mathrm{N}(\mathrm{x}=2-3,4)$. The modified microstructures of the nitrided steel containing mainly the $\varepsilon \mathrm{N}$ and $\mathrm{Fe}_{4} \mathrm{~N}$ nitrides are responsible for the corrosion resistance properties.

\section{Conclusions}

Martensitic tool steel after elevated temperature plasma nitriding shows the enhancement of resistance to corrosion significantly. $\mathrm{Fe}_{\mathrm{x}} \mathrm{N}(\mathrm{x}=2-3,4)$ phases were found on the surface microstructure after nitriding. $\varepsilon \mathrm{N}$ phase in the modified microstructure is responsible for the resistance to corrosion. Both the nitrided sample treated for 8 and $10 \mathrm{~h}$ show better corrosion resistance when compared to bare steel. However, the improvement of corrosion resistance of both these steels was found to be almost similar. The tool life in the harsh corrosive atmosphere can be prolonged after nitriding. This would be beneficial for machining and tool industries.

\section{Acknowledgements}

The encouragements and support by GITAM (Deemed to be University) is thankfully acknowledged. Valuable discussions and support from ENSAM, France is gratefully acknowledged.

\section{References}

[1] Corinne Nouveau, M.A. Djouadi, R. Marchal, M. Lambertin, Méca Indus 3 (2002) 333.

[2] M. Van Stappen, M. Kerkhofs, L.M. Stals, C. Quaeyhaegens, Surf Coat. Technol. 629 (1995) 74-75.

[3] M. Ohring, The Material Science of Thin Films, Academic, San Diego, 1992.

[4] T. Michler, Influence of plasma nitriding on hydrogen environment embrittlement of austenitic stainless steel, Surf. Coat. Technol. 202 (2008) $1688-1695$.

[5] L. Wang, Y. Li, X. Wu, Plasma nitriding of low alloy steels at floating and cathodic potentials, Appl. Surf. Sci. 254 (2008) 6595-6600.

[6] A. Maniee, F. Mahboubi, R. Soleimani, The study of tribological and corrosion behavior of plasma nitrided 34CrNiMo6 steel under hot and cold wall conditions, Mater. Des. 60 (2014) 599-604.

[7] J. O’Brien, D. Mand Goodman, Plasma (Ion) Nitriding, Metals Handbook, American Society for Metals, Metals Park, OH, 1991, pp. 420-424.

[8] D. Cherng Wen, Microstructure and corrosion resistance of the layers formed on the surface of precipitation hardenable plastic mold steel by plasma nitriding, Appl. Surf. Sci. 256 (2009) 797-804.

[9] C. Nouveau, P. Steyer, K. Ram Mohan Rao, D. Lagadrillere, Plasma nitriding of $90 \mathrm{CrMoV} 8$ tool steel for the enhancement of hardness and corrosion resistance, Surf. Coat. Technol. 205 (2011) 4514-4520.

[10] R.M. Muñoz Riofano, L.C. Castteleti, L.C.F. Canale, G.E. Totten, Improved wear resistance of $\mathrm{P} / \mathrm{M}$ tool steel alloy with different vanadium contents after ion nitriding, Wear 265 (2008) 57-64.

[11] E. Arslan, M.C. Igdil, H. Yazici, et al., Mechanical properties and biocompatibility of plasma-nitrided laser-cut 316L cardiovascular stents, J. Mater. Sci. 19 (2008) 2079-2086, https://doi.org/10.1007/s10856-007-3302-4.

[12] Janine K.F.S. Braz, Gabriel M. Martins, Vladimir Sabino, Jussier O. Vitoriano, Carlos Augusto G. Barboza, Ana Katarina M. C. Soares, Hugo A. O. Rocha, Moacir. F. Oliveira, Clodomiro Alves Junior, Carlos Eduardo B. Moura, Plasma nitriding under low temperature improves the endothelial cell biocompatibility of 316L stainless steel, Biotechnol. Lett., (2019), doi: 10.1007/s10529-019-02657-7(0).

[13] G.-H. Zhao, R.E. Aune, N. Espallargas, Tribocorrosion studies of metallic biomaterials: the effect of plasma nitriding and DLC surface modifications, J. Mech. Behav. Biomed. Mater. 63 (2016) 100-114, https://doi.org/10.1016/J. JMBBM.2016.06.014.].

[14] H. Forati Rad, A. Amadeh, H. Moradi, Wear assessment of plasma nitrided AISI H11 steel, Mater. Des. 32 (2011) 2635-2643.

[15] A. Mashreghi, S. Soleimani, S. Saberifar, The investigation of wear and corrosion behavior of plasma nitrided DIN 1.2210 cold work tool steel, Mater. Des. 46 (2013) 532-538. 